ELORE (ISSN 1456-3010), vol. $16-1 / 2009$.

Julkaisija: Suomen Kansantietouden Tutkijain Seura ry.

[http://www.elore.fi/arkisto/1_09/kirjat_leppalahti_01_09.pdf]

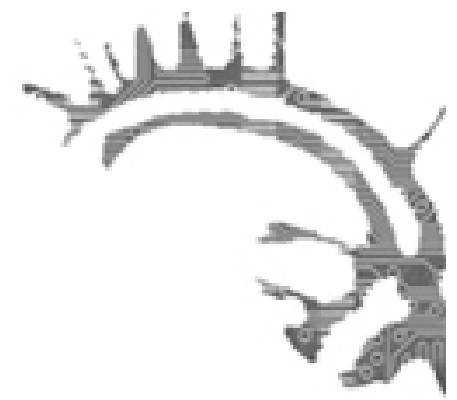

\title{
KIRJA-ARVIO:
}

\section{EI NIMI MIESTÄ PAHENNA, MUTTA PALJON SE KERTOO}

Kotilainen, Sofia 2008: Suvun nimissä. Nimenannon käytännöt Sisä-Suomessa 1700-luvun alusta 1950-luvulle. Bibliotheca Historica 120. Helsinki: SKS. 423 sivua.

\section{Merja Leppälahti}

Oma nimi on ihmisyksilölle hyvin tärkeä asia, sitä on nimitetty suorastaan portiksi identiteettiin (Sjöblom 2006, 257). Ihmisen itsensä lisäksi hänen nimellään on merkitystä ympäristölle. Nimi paitsi kertoo muille, kuka juuri tämä kysymyksessä oleva henkilö on, myös kantaa tietoja ja muistoja hänen suvustaan.

Sofia Kotilainen tarkastelee väitöskirjassaan Kivijärven alueella nykyisessä Keski-Suomessa eläneiden Kotilaisen ja Hakkaraisen sukujen nimistöä 1700-luvulta 1900-luvun puoliväliin pääasiassa kirkonkirjojen ja muiden asiakirjatietojen valossa. Lisäksi Kotilainen käyttää Kotimaisten kielten tutkimuskeskuksen nimiarkiston kokoelmia sekä Suomalaisen Kirjallisuuden Seuran muistitietoaineistoa, joka on kerätty hänen tutkimusalueeltaan tai koskee sitä. Nimistön tarkastelun lisäksi Kotilaisen tutkimuksessa tulee esille monenlaisia kiinnostavia pikku huomioita. Hän esimerkiksi toteaa, että nykyajan käsitys entisajan väestön paikallaan pysymisestä on osittain virheellinen. Vaikka tavallisesti ei matkusteltu siinä määrin kuin nykyään, esimerkiksi palveluspaikkojen ja muiden töiden vuoksi tapahtui jatkuvasti pientä liikettä myös pitäjänrajan yli. Tutkimusalue sijoittuu jännittävästi itäisen ja läntisen tradition keskeisalueiden välimaastoon, mikä tuottaa tarkasteluihin oman mielenkiintoisen lisänsä.

Kotilainen tekee nimistöntutkimusta, mutta tarkastelee nimiä ja nimenantoperusteita kulttuurihistoriallisesta näkökulmasta. Hän käsittelee myös sukunimiä ja lisänimiä, mutta erityisesti tutkimus keskittyy etunimiin ja niiden todennäköisiin ja mahdollisiin lähteisiin. Itsekin sukututkimusta tehneenä olen voinut kuvitella, että tie- 
tyn kylän sukukuntien erityisen runsaat Matit ja Mariat tai Juhot ja Liisat johtuvat ajan suppeaan nimivalikoimaan liittyvistä sattumista. Kotilainen osoittaa, että kysymyksessä voi olla muutakin. Hän löytää mielenkiintoisia yhteyksiä perinteisiin suvun nimiin, esimerkiksi tietyissä tilanteissa esikoispoika saa usein isänpuoleisen isoisänsä nimen. Etunimissä on muotivaihtelua, mutta nimeä ei yleensä valita sattumanvaraisesti vaan on suorastaan todennäköistä, että lapsesta tulee jonkun sukulaisen tai kummin kaima.

\section{ASIAKIRJAT TOSIMAAILMAN KUVASTAJINA}

Kirkonkirjoissa samasta nimestä voi saman henkilön kohdalla esiintyä monia variaatioita. Esimerkiksi perheen lasten syntyessä saman äidin nimi voidaan kirjoittaa monella eri tavalla. Usein voi päätellä, mikä on ollut käytössä oleva nimimuoto, mutta läheskään aina ei voi tehdä varmoja johtopäätöksiä. Toisinaan kirkonkirjoissa ja muissa teksteissä esiintyy myös selvästi käytössä olleita lempinimiä, kuten Hessu.

Kotilaisen tutkimusalueella väestö oli suomenkielistä, mutta kirkonkirjat pidettiin ruotsiksi 1860-luvulle, osin vuoteen 1883 saakka. Erityisesti sukututkijoiden käytössä on olemassa suosituksia ruotsiksi kirkonkirjoihin merkittyjen nimen suomenkielisiksi vastineiksi. Kotilainen ei ole kuitenkaan halunnut omassa tutkimuksessaan kääntää etunimiä mekaanisesti suomalaisiksi. Hän myös arvelee, että käytössä saattoi olla erilaisia nimiä. Esimerkiksi Maria Christinaksi kastekirjoissa merkitty nainen oli todennäköisesti arkipuheessa Maijastiina, mutta hän saattoi mahdollisesti itsekin käyttää virallisessa yhteydessä ruotsinkielistä nimeään.

Kun nimi kertoi kantajastaan, se myös paljasti ei-toivottuja asioita. Esimerkiksi avioton syntyperä on ollut melko tavallinen, mutta häpeällinen asia koko Kotilaisen tutkimuksen ajankohtana. Pahimmillaan tieto seurasi koko elämän äidinnimestä muodostetun matronyymin muodossa, Pekka Maijanpoika oli äpärälapsi vielä aikuisenakin. Tutussa ympäristössä muistutus syntyperästä säilyi myös siinä, että käytettiin äidin sukunimeä eikä isän. Melko monet aviottomien lasten äidit menivät myöhemmin naimisiin lapsen isän kanssa, jolloin lapsi tavallisesti siirtyi isän nimelle. Kotilainen osoittaa, että avioton poikalapsi saattoi myös saada isänsä etunimen, ehkä juuri todisteena isyydestä. Kiinnostava huomio on myös se, että aviottomat lapset saivat muita enemmän erikoisia ja harvinaisia nimiä.

\section{NiMi MIESTÄ MYÖTEN}

Kotilainen toteaa tutkimuksessaan, miten ihmisillä on saattanut olla monia nimiä, joita on käytetty eri tilanteissa. Etunimien osalta jokaisella on ollut kirjoihin merkityt viralliset nimet sekä arkielämässä käytetyt nimet, kuten Johan, Juho ja Jussi. Sukunimi on ollut melko pysyvä, mutta sekin on saattanut joskus vaihtua. Sukunimen lisäksi on tarvittu lisämääreitä, kun paikkakunnalla on asunut runsaasti samojen sukujen jälkeläisiä, joilla on samoja etunimiä. Tällöin määrittäjänä on ollut usein talon tai isän 


\section{MERJA LePPÄLAHTI}

nimi, ja varsinkin naisilla myös puolison nimi. Lisänimiä on annettu myös ominaisuuksien, tapojen tai työn mukaan, esimerkiksi Tuota-Ville tai Hauta-Poavo. Lisäksi erityisesti syrjäisen Kinnulan kylän asukkaita on kollektiivisesti nimitetty monenlaisilla pejoratiivisilla pilkkanimillä, joihin on liittynyt halventavia sanontoja.

Sofia Kotilainen käyttää tutkimuksessaan myös sukutarinoita. Esimerkiksi "Lastu joessa" -tarina liitetään myös Kotilaisen sukuun. Kysymyksessä ollut Kotilainen lähti joessa näkemänsä lastun vuoksi katsomaan, kuka hänen kaskimailleen oli asettunut. Tulijan kanssa syntyi riita, jonka päätteeksi Kotilainen tappoi tunkeilijan. Riidoista saman Pölkin suvun kanssa on muitakin tarinoita, jotka voivat päättyä onnellisemmin.

Kotilaisen keskeisenä tutkimusaiheena ovat tietyn ajanjakson, alueen ja sukujen nimenantokäytännöt. Lisäksi Kotilainen on väitöskirjassaan onnistunut tavoittamaan paljon menneisyyden kiinnostavia yksityiskohtia, jotka muodostavat mielenkiintoisen katsauksen Kotilaisen ja Hakkaraisen sukujen vaiheisiin ja henkilöihin. Runsaat liitteet mahdollistavat nimenantokäytäntöjen yksityiskohtien tarkastelemisen myös selkeässä taulukkomuodossa, jos on erityisesti siitä kiinnostunut. Lisäksi mukana ovat asiaankuuluvat henkilö-, paikan- ja tilanimihakemistot sekä asiasanahakemisto.

\section{KiRjallisuUs}

SJÖBLOM, PAULA 2006: Toiminimen toimenkuva. Suomalaisen yritysnimistön rakenne ja funktiot. Helsinki: SKS.

Filosofian lisensiaatti Merja Leppälahti on folkloristiikan jatko-opiskelija Turun yliopistossa. 